\title{
Transurethral Resection of Prostate: A Comparison of Standard Monopolar versus Bipolar Saline Resection
}

\author{
Piyush Singhania, Dave Nandini, Fernandes Sarita, Pathak Hemant, Iyer Hemalata
}

Department of Urology (PS, PH) and Anesthesiology (DN, FS, IH), T N Medical College \& B Y L Nair Hospital, Mumbai, India

\begin{abstract}
Introduction: Transurethral resection syndrome is an uncommon but potentially life threatening complication. Various irrigating solutions have been used, normal saline being the most physiological. The recent availability of bipolar cautery has permitted the use of normal saline irrigation.

Material and Methods: In a randomized prospective study, we compared the safety and efficacy of bipolar cautery (using $0.9 \%$ normal saline irrigation) versus conventional monopolar cautery (using $1.5 \%$ glycine irrigation). Pre and postoperative hemoglobin $(\mathrm{Hb})$ and hematocrit values were compared. Hemodynamics and arterial oxygen saturation were monitored throughout the study. Safety end points were changes in serum electrolytes, osmolarity and Hb/PCV (packed cell volume). Efficacy parameters were the International Prostate Symptom Score (IPSS) and Qmax (maximum flow rate in $\mathrm{mL} / \mathrm{sec}$ ) values.

Results: Mean preoperative prostate size on ultrasound was $60 \pm 20 \mathrm{cc}$. Mean resected weight was $17.6 \pm 10.8 \mathrm{~g}$ (glycine) and $18.66 \pm 12.1 \mathrm{~g}$ (saline). Mean resection time was $56.76 \pm 14.51 \mathrm{~min}$ (glycine) and $55.1 \pm 13.3 \mathrm{~min}$ (saline). The monopolar glycine group showed a greater decline in serum sodium and osmolarity (4.12 meq/L and 5.14 mosmol/L) compared to the bipolar saline group $(1.25 \mathrm{meq} / \mathrm{L}$ and $0.43 \mathrm{mosmol} / \mathrm{L})$. However, this was not considered statistically significant. The monopolar glycine group showed a statistically significant decline in $\mathrm{Hb}$ and PCV $(0.97 \mathrm{gm} \%, 2.83, \mathrm{p}<$ $0.005)$ as compared to the bipolar saline group $(0.55 \mathrm{gm} \%$ and $1.62, \mathrm{p}<0.05)$. Patient follow- up $(1,3,6$ and 12 months postoperatively) demonstrated an improvement in IPSS and Qmax in both the groups.

Conclusion: We concluded that bipolar transurethral resection of prostate is clinically comparable to monopolar transurethral resection of prostate with an improved safety profile. However, larger number of patients with longer follow up is essential.
\end{abstract}

Key words: prostate; transurethral resection of prostate; sline; glycine

Int Braz J Urol. 2010; 36: 183-9

\section{INTRODUCTION}

Transurethral resection of prostate (TURP) is a standard operative procedure for patients with benign prostrate hypertrophy. Irrigants used range from distilled water to a variety of non-hemolytic solutions like glycine, saline, sorbitol and mannitol.
Irrigant fluid absorption by the patient is a potentially serious complication of TURP, resulting in the TURP syndrome with appreciable morbidity and mortality $(1,2)$.

As an isotonic electrolyte medium, normal saline is the most physiologic irrigant for TURP, but its electrical conducting properties prohibit its use 
with conventional monopolar cautery. The development of bipolar resection systems now permits the use of normal saline as an irrigant. Use of bipolar cautery has been reported to be associated with less collateral and penetrative tissue damage, lower incidence of TURP syndrome, shorter catheter indwelling times and earlier hospital discharge (3-7). This study was undertaken to compare the safety and efficacy of bipolar cautery using saline as an irrigant with conventional monopolar cautery using glycine as an irrigant.

\section{MATERIALS AND METHODS}

Following Institutional Ethics Committee approval and informed consent from patients, we studied 60 patients with a diagnosis of benign enlargement of the prostate undergoing TURP. They were divided into two groups using standard randomization codes. Group I $(\mathrm{n}=30)$ had TURP performed with monopolar cautery using $1.5 \%$ glycine as an irrigant. In Group II $(n=30)$, bipolar cautery was used with $0.9 \%$ saline as irrigant. Indications for surgery included failed medical therapy, acute urinary retention with failed voiding trial, recurrent urinary tract infection and hematuria. Patients with documented or suspected prostate cancer, neurogenic bladder, previous prostate surgery, urethral stricture, associated bladder stones and renal impairment were excluded from the study.

Preoperative International Prostate Symptom Score (IPSS), Qmax (maximum flow rate in $\mathrm{mL} / \mathrm{second}$ ) and prostate volume by ultrasound were recorded, as well as patient age, weight and height. Preoperative blood investigations included complete hemogram, liver and renal function tests, chest X-ray and electrocardiogram. Surgery was performed by trainees and consultants (4 surgeons).

Surgery was performed under spinal anesthesia in all patients. Patients received $10 \mathrm{~mL} / \mathrm{kg}$ of normal saline intravenously prior to administration of spinal block. Normal saline infusion was continued in the intraoperative period. External jugular vein was cannulated and a baseline sample $(2 \mathrm{~mL})$ sent for estimation of serum sodium, potassium and osmolarity. These tests were repeated every 15 minutes until the end of the procedure. Baseline and post procedure hemoglobin and hematocrit values were also studied. Resection time, volume of irrigant used, weight of the resected gland and duration of surgery in both the groups were recorded. The patients vital parameters (pulse, blood pressure, oxygen saturation monitoring by pulse oximeter) were monitored and clinical signs of transurethral resection (TUR) syndrome were watched for.

Bipolar resection was performed using the Gyrus PK bipolar resection system. Generator settings for cutting and coagulation were 160-180 W and $100-120 \mathrm{~W}$ respectively. Monopolar resection was performed using Erbee cautery with cutting and coagulation setting of 100 and $60 \mathrm{~W}$ respectively.

Barnes method of resection was used in all our patients. The resectoscope used was 26 Fr Modified Iglesias double sheath continuous irrigation resectoscope with thumb operating working element. The height of the irrigation fluid was $60 \mathrm{~cm}$ in all cases. To prevent thermal damage to the urethra, we used copious amounts of jelly around the sheath in the urethra and always carefully monitored any early exchange of worn loops and discarding of loops with distortion or insulation faults.

Postoperative irrigation was used to ensure clear catheter drainage. Catheter removal was done on postoperative Day 2 in all cases.

Patients were followed-up at 1, 3, 6 and 12 months with the IPSS reassessment and Qmax obtained using rotating disc type uroflowmeter.

The Student-t- test was used to compare the parametric data between the groups i.e.; age, weight, height, volume of the irrigant, resection time and weight of resected gland. ANOVA test was used to compare hemoglobin (Hb), packed cell volume (PCV), osmolarity, serum electrolyte changes, IPSS and Qmax in the groups p value $<0.05$ was considered significant and a value $<0.005$ highly significant.

\section{RESULTS}

Demographic profiles in both the groups were comparable (Table-1). Also comparable were preoperative $\mathrm{Hb}$, hematocrit, osmolarity and serum electrolytes (Table-2). Prostate size on ultrasound 
Table 1 - Age, height and weight profile.

\begin{tabular}{lccc}
\hline Variable & Monopolar Mean (SD) & Bipolar Mean (SD) & Significance \\
\hline Age (year) & $65.96(6.6)$ & $63.86(6.1)$ & $\begin{array}{c}\mathrm{p}>0.05 \\
\text { not significant } \\
\mathrm{p}>0.05 \\
\text { Height }(\mathrm{cm})\end{array}$ \\
Weight $(\mathrm{kg})$ & $171.33(5.99)$ & $170.93(5.4)$ & $\begin{array}{c}\text { not significant } \\
\mathrm{p}>0.05 \\
\text { not significant }\end{array}$ \\
\hline
\end{tabular}

$S D=$ standard deviation.

Table 2 - Comparison of electrolytes, osmolarity, hemoglobin and hematocrit between bipolar and monopolar groups.

\begin{tabular}{|c|c|c|c|c|c|c|}
\hline \multirow[t]{2}{*}{ Variable } & \multicolumn{2}{|c|}{ Preoperative } & \multicolumn{2}{|c|}{ Postoperative } & \multicolumn{2}{|c|}{ p Value } \\
\hline & $\begin{array}{l}\text { Glycine } \\
\text { (variance) }\end{array}$ & $\begin{array}{c}\text { Saline } \\
\text { (variance) }\end{array}$ & $\begin{array}{l}\text { Glycine } \\
\text { (variance) }\end{array}$ & $\begin{array}{c}\text { Saline } \\
\text { (variance) }\end{array}$ & Glycine & Saline \\
\hline $\begin{array}{l}\text { Sodium } \\
(\mathrm{mEq} / \mathrm{L})\end{array}$ & $\begin{array}{c}132.59 \\
40.75\end{array}$ & $\begin{array}{r}132.93 \\
68.72\end{array}$ & $\begin{array}{c}128.47 \\
70\end{array}$ & $\begin{array}{c}131.68 \\
39.57\end{array}$ & NS & NS \\
\hline $\begin{array}{l}\text { Potassium } \\
(\mathrm{mEq} / \mathrm{L})\end{array}$ & $\begin{array}{c}4.036 \\
0.38\end{array}$ & $\begin{array}{r}4.217 \\
0.42\end{array}$ & $\begin{array}{c}3.843 \\
0.51\end{array}$ & $\begin{array}{c}3.789 \\
0.45\end{array}$ & NS & NS \\
\hline $\begin{array}{l}\text { Osmolarity } \\
(\mathrm{mMol} / \mathrm{L})\end{array}$ & $\begin{array}{l}294.54 \\
128.27\end{array}$ & $\begin{array}{r}285.85 \\
59.47\end{array}$ & $\begin{array}{c}289.36 \\
67.25\end{array}$ & $\begin{array}{c}285.42 \\
63.61\end{array}$ & NS & NS \\
\hline $\begin{array}{l}\text { Hemoglobin } \\
(\mathrm{g} / \mathrm{dL})\end{array}$ & $\begin{array}{c}12.35 \\
3.17\end{array}$ & $\begin{array}{c}12.26 \\
1.72\end{array}$ & $\begin{array}{l}11.38 \\
2.18\end{array}$ & $\begin{array}{r}11.71 \\
2.05\end{array}$ & $\begin{array}{c}3.27 \times 10^{-7} \\
\mathrm{~S}\end{array}$ & $\begin{array}{c}0.014 \\
\mathrm{~S}\end{array}$ \\
\hline $\begin{array}{l}\text { Hematocrit } \\
(\%)\end{array}$ & $\begin{array}{l}38.15 \\
25.91\end{array}$ & $\begin{array}{l}38.60 \\
17.64\end{array}$ & $\begin{array}{l}35.32 \\
12.48\end{array}$ & $\begin{array}{l}36.98 \\
18.54\end{array}$ & $\begin{array}{c}1.81 \times 10^{-5} \\
\mathrm{~S}\end{array}$ & $\begin{array}{c}0.008 \\
\mathrm{~S}\end{array}$ \\
\hline
\end{tabular}

$N S=$ not significant

ranged from 40-80 cc. Weight of resected gland, resection time and volumes of irrigant used were comparable (Table-3).

The monopolar glycine group showed a greater decline in serum sodium $(4.12 \mathrm{meq} / \mathrm{L})$ compared to the bipolar saline group $(1.3 \mathrm{meq} / \mathrm{L})$. However, this was not statistically significant between the groups ( $p$ $=0.93$ for bipolar and $\mathrm{p}=0.2$ for monopolar group respectively). Serum osmolarity declined in the monopolar glycine group by $5.14 \mathrm{mosm} / \mathrm{L}$ as compared to $0.43 \mathrm{mosm} / \mathrm{L}$ in the bipolar glycine group. This decline in osmolarity from the preoperative value was not significant in either group, $p>0.05$. Serum potassium values showed no significant change in either group $(p>0.05)$. The monopolar glycine group showed a statistically highly significant decline in $\mathrm{Hb}(0.97 \mathrm{gm} \%, \mathrm{p}<0.005)$ from the preoperative value. In comparison, the bipolar group showed a smaller drop in hemoglobin (0.55 gm \%, p = 0.014). Hematocrit values showed a similar trend with the glycine monopolar group recording a more significant fall from the preoperative value as compared to the bipolar saline group $(2.83, \mathrm{p}<0.005$ and $1.62, \mathrm{p}<$ 0.05 respectively) (Table-2). 
Table 3 - Comparison of intraoperative variables between bipolar and monopolar groups.

\begin{tabular}{lccc}
\hline Variable & $\begin{array}{c}\text { Glycine } \\
\text { mean (SD) }\end{array}$ & $\begin{array}{c}\text { Saline } \\
\text { mean (SD) }\end{array}$ & Significance \\
\hline Volume of irrigant (L) & $19.8(5.4)$ & $18.76(8.1)$ & $\begin{array}{c}\mathrm{p}>0.05 \\
\text { not significant } \\
\mathrm{p}>0.05 \\
\text { Resection time (min) }\end{array}$ \\
Resected weight (g) & $56.76(14.51)$ & $55.1(13.3)$ & $\begin{array}{c}\text { not significant } \\
\mathrm{p}>0.05 \\
\text { not significant }\end{array}$ \\
\hline
\end{tabular}

$S D=$ standard deviation

Table 4-Comparison of IPSS between bipolar and monopolar groups.

\begin{tabular}{lccl}
\hline Time & $\begin{array}{c}\text { BIPOLAR } \\
\text { IPSS } \\
\text { mean (SD) }\end{array}$ & $\begin{array}{c}\text { MONOPOLAR } \\
\text { IPSS } \\
\text { mean (SD) }\end{array}$ & p Value \\
\hline Pre-op & $24.07(3.68)$ & $23.43(4.04)$ & $0.539 \mathrm{NS}$ \\
Post-op 1 mo & $7.73(0.83)$ & $7.47(0.90)$ & $0.237 \mathrm{NS}$ \\
Post-op 3 mo & $6.77(1.04)$ & $6.60(1.04)$ & $0.537 \mathrm{NS}$ \\
Post-op 6 mo & $6.30(0.95)$ & $6.40(0.97)$ & $0.688 \mathrm{NS}$ \\
Post-op 12 mo & $6.13(0.94)$ & $6.23(0.94)$ & $0.681 \mathrm{NS}$ \\
\hline
\end{tabular}

IPSS = International Prostate Symptoms Score; SD = standard deviation.

The surgeons reported better coagulation and a clearer operative field with the bipolar resectoscope. None of our patients had any ureteric orifice injury and no procedure was abandoned due to capsular perforation. None of our patients required blood transfusion or recatheterisation for clot retention. Also, none of our patients required any intervention in the postoperative follow-up, i.e. reoperation, treatment of strictures or bladder neck contractures. None of our patients had any documented urinary tract infection, epididymitis or myocardial infarction in the postoperative follow-up.

Patient follow-up $(1,3,6$ and 12 months postoperatively) demonstrated an improvement in IPSS and Qmax in both the groups. The improvement in IPSS was comparable in both groups (Table-4). The Qmax at follow-up was significantly higher in the bipolar group as compared to the monopolar group $(\mathrm{p}<0.05$, Table-5).

\section{COMMENTS}

Our understanding of the pathophysiology leading to TURP syndrome has improved in recent years. Recent technological advances have led to the development of new bipolar resection systems that permit normal saline to be used as irrigant. 
TURP: Comparison of Monopolar vs. Bipolar Resection

Table 5 - Comparison of Qmax between bipolar and monopolar groups.

\begin{tabular}{lccc}
\hline Time & $\begin{array}{c}\text { Bipolar } \\
\text { Qmax }(\mathbf{m L} / \mathbf{s}) \\
\text { mean (SD) }\end{array}$ & $\begin{array}{c}\text { Monopolar } \\
\text { Qmax (mL/s) } \\
\text { mean (SD) }\end{array}$ & p Value \\
\hline Pre-op & $6.59(2.51)$ & $6.44(2.28)$ & $0.827 \mathrm{NS}$ \\
Post-op 1 months & $17.92(2.16)$ & $14.04(2.59)$ & $<0.05 \mathrm{~S}$ \\
Post-op 3 months & $18.44(1.93)$ & $14.91(2.29)$ & $<0.05 \mathrm{~S}$ \\
Post-op 6 months & $18.42(2.76)$ & $15.30(2.33)$ & $<0.05 \mathrm{~S}$ \\
Post-op 12 months & $18.52(2.07)$ & $15.42(2.31)$ & $<0.05 \mathrm{~S}$ \\
\hline
\end{tabular}

Qmax $=$ maximum flow rate $; S D=$ standard deviation .

Recent trials evaluating the safety and efficacy of bipolar resectoscopes have claimed advantages over standard monopolar resection (3-7). By using physiologic saline $(0.9 \% \mathrm{NaCl})$ as irrigation fluid, it eliminates any danger of TUR syndrome and thus eliminates the conventional time limit of resection. The bipolar system can be used as safely and effectively in the resection of the large gland $(>60 \mathrm{~g})$ as reported in the resection of small and medium-sized glands (8). Collateral and penetrative tissue damage is reduced, there is less tissue charring, better identification of the surgical capsule and less granulation tissue formation.

Our study showed a fall of $1.3 \mathrm{mEq} / \mathrm{L}$ in the serum sodium concentration in the saline bipolar group. In a small pilot study by Issa et al., it was observed that despite a prolonged resection time, the mean drop in serum sodium concentration was only $1.6 \mathrm{mEq} / \mathrm{L}$ (9). In comparison, the glycine monopolar group showed an appreciable decline in sodium levels $(4.12 \mathrm{mEq} / \mathrm{L})$. However, the drop in sodium was not statistically significant.

The crucial physiological derangement of the central nervous system functions during TURP syndrome is not hyponatremia per se but acute hypoosmolarity. Only a few studies correlate a patient outcome after TURP with both serum sodium concentration and osmolarity. In a series of 72 patients undergoing TURP, serum sodium concentration decreased by 10 to $54 \mathrm{mmol} / \mathrm{L}$ in $19(26 \%)$ while osmolarity changed in only two (3\%). The two patients who had both hyponatremia and hypoosmolarity developed pulmonary edema and encephalopathy. The 5 patients in this series with the largest decreases in serum $\mathrm{Na}$ concentration had no changes in serum osmolarity and no signs of TURP syndrome. As serum Na concentration does not necessarily reflect serum osmolarity, the recommendation is that serum $\mathrm{Na}$ concentration should be reported together with osmolarity when the irrigant solution contains osmotically active solutes such as glycine (1).

Our study showed a drop in osmolarity of $5.14 \mathrm{mosmol} / \mathrm{L}$ in the glycine group compared to a drop of $0.43 \mathrm{mosmol} / \mathrm{L}$ in the saline group. This drop, however, was not statistically significant.

Plasma potassium fluctuations have also been studied during endourological procedures. Norlen et al. (10) reported dilutional hypokalemia when distilled water was used as an irrigant. In contrast, Krishna Moorthy et al. (11) reported significant hyperkalemia in patients undergoing TURP and percutaneous nephrostolithotomy with glycine and sterile water, probably due to hemolysis during absorption of fluid into the circulation. There was no alteration in potassium levels when normal saline was used as irrigating fluid. Hyperkalemic cardiotoxicity is increased by hyponatremia and acidosis. It is possible that the cardiovascular changes occurring in TURP syndrome can be a combination of both hyponatremia and hyperkalemia. Our study, however, showed no significant changes in potassium levels in either group.

Issa and coworkers report their experience with large prostate resections and only a minimal fall in hematocrit with the bipolar resectoscope (9). 
Our study results showed a highly significant drop in hematocrit and $\mathrm{Hb}$ in the monopolar-glycine group $(2.83 \%, 0.97 \mathrm{gm} \%$ respectively). There was however a significant drop in hematocrit $(1.62 \%)$ and $\mathrm{Hb}(0.55$ $\mathrm{gm} \%)$ in the bipolar-saline group also. However, no patient from either group required blood transfusion.

In our study, the resection was done by trainee residents who were at different stages of their learning curves. This may explain comparable operating time in both groups. Michielsen et al. have reported significantly longer operating times with bipolar resection (12). Recent studies have shown shorter operating times, less blood loss and shorter periods of irrigation and catheterization with bipolar resection $(13,14)$. Improvement in Qmax in our study was significantly higher with the bipolar group although IPSS was comparable in both the groups.

\section{CONCLUSION}

Our study results indicate that bipolar TURP is clinically comparable to monopolar TURP with an improved safety profile. Bipolar saline TURP may prove safer in patients with large prostates where longer resection time and greater absorption of irrigating fluid is a concern. However, larger numbers of patients with longer follow-up is essential.

\section{ACKNOWLEDGEMENTS}

The authors thank the Research Society, BYL Nair Hospital for their support of this study.

\section{CONFLICT OF INTEREST}

None declared.

\section{REFERENCES}

1. Gravenstein D: Transurethral resection of the prostate (TURP) syndrome: a review of the pathophysiology and management. Anesth Analg. 1997; 84: 438-46.
2. Hahn RG: Fluid absorption in endoscopic surgery. $\mathrm{Br}$ J Anaesth. 2006; 96: 8-20.

3. Issa MM: Technological advances in transurethral resection of the prostate: bipolar versus monopolar TURP. J Endourol. 2008; 22: 1587-95.

4. Martis G, Cardi A, Massimo D, Ombres M, Mastrangeli B: Transurethral resection of prostate: technical progress and clinical experience using the bipolar Gyrus plasmakinetic tissue management system. Surg Endosc. 2008; 22: 2078-83.

5. Ho HS, Cheng CW: Bipolar transurethral resection of prostate: a new reference standard? Curr Opin Urol. 2008; 18: 50-5.

6. Singh H, Desai MR, Shrivastav P, Vani K: Bipolar versus monopolar transurethral resection of prostate: randomized controlled study. J Endourol. 2005; 19: 333-8.

7. Ho HS, Yip SK, Lim KB, Fook S, Foo KT, Cheng CW: A prospective randomized study comparing monopolar and bipolar transurethral resection of prostate using transurethral resection in saline (TURIS) system. Eur Urol. 2007; 52: 517-22.

8. Bhansali M, Patankar S, Dobhada S, Khaladkar S: Management of large (>60 g) prostate gland: PlasmaKinetic Superpulse (bipolar) versus conventional (monopolar) transurethral resection of the prostate. $\mathrm{J}$ Endourol. 2009; 23: 141-5.

9. Issa MM, Young MR, Bullock AR, Bouet R, Petros JA: Dilutional hyponatremia of TURP syndrome: a historical event in the 21st century. Urology. 2004; 64: 298-301.

10. Norlén H, Dimberg M, Vinnars E, Allgén LG, Brandt $\mathrm{R}$ : Water and electrolytes in muscle tissue and free amino acids in muscle and plasma in connection with transurethral resection of the prostate. I. Distilled water as an irrigating fluid. Scand J Urol Nephrol. 1990; 24: 21-6.

11. Krishna Moorthy H, Philip S: Serum Electrolytes In TURP Syndrome- Is The Role Of Potassium UnderEstimated? Indian J. Anaesth. 2002; 46: 441-4.

12. Michielsen DP, Debacker T, De Boe V, Van Lersberghe C, Kaufman L, Braeckman JG, et al.: Bipolar transurethral resection in saline--an alternative surgical treatment for bladder outlet obstruction? J Urol. 2007; 178: 2035-9; discussion 2039.

13. M.I.Karaman, M Gurdal, M Zturk, CKaya, S Kirecci, N Pirincci: The comparison of transurethral vaporization using plasmakinetic energy and transurethral resection of prostate: A randomized prospective trial with 1 year followup. J Endourol. 2004; 18: (Supp 1): A 77 . 
14. Patankar S, Jamkar A, Dobhada S, Gorde V: PlasmaKinetic Superpulse transurethral resection versus conventional transurethral resection of prostate. J Endourol. 2006; 20: 215-9.

Accepted after revision:

October 20, 2009

Correspondence address:

Dr. Piyush Singhania

203, City Hillview Apts

Plot no. 13, Sector 19

Nerul, Navi Mumbai, India

E-mail: piyushsnghn@yahoo.co.in 